\title{
Volume 6 Issue 2: Editorial
}

\author{
Sarah Attfield, University of Technology Sydney \\ Liz Giuffre, University of Technology Sydney
}

This is now the fourth issue of the Journal that has been produced since the Covid-19 pandemic began. At various points we have highlighted the effects of the pandemic on working-class people around the world and have hoped that the stark reminders of inequality brought by the pandemic would have some impact on policy makers and people in power. What we have seen is working-class people praised and even celebrated for the work they have done to keep societies functioning during lockdowns, but little in the way of tangible difference (at least in the long term) to working-class people's lives. All the talk of 'essential workers' has not necessarily translated to improvements in wages and conditions. But - there have been some victories. No thanks to the bosses, but due to the organisation and mobilisation of workers. Unions have been established, there has been industrial action, and there have been wins along the way. We see that it is collective action and worker solidarity that leads to positive change.

We aren't willing to make any predictions about 2022. The pandemic has shown that everything can change in a matter of days. But we do know that the Journal of Working-Class Studies goes from strength to strength, and that the field of working-class studies is vibrant and continually growing. In 2021, members of the Working-Class Studies Association ran the inaugural Irish working-class studies conference, mostly online, via Dublin. The success of that conference shows that there are many people globally who are interested and committed to working-class studies and to advocating for working-class people as well as doing the important work of demonstrating how class operates. This issue of the Journal also continues to showcase this commitment to working-class studies, with seven articles and nine book reviews.

The first article, 'The Transformations of Greek Working-Class Fiction from the Interwar Period to the Present' by Vasiliki Petsa, Sofia Zisimopoulou, Anastasia Natsina, andnIoannis Dimitrakakis, takes the reader on a survey of modern Greek fiction from the interwar years through to the present day, and suggests that there are some themes and styles of such literature that run across the decades. The authors offer a fascinating insight into Greek working-class literature that will no doubt encourage readers to seek out some of the works they analyse.

Wendy L. Wright follows with an analysis of bail reform in the US in 'Running head: Bail, Reform, and Foucault's Dangerous Individual', and argues that approaches to reform can be problematic, because they do not address the ways that individuals accused of crimes are labelled as dangerous and deviant due to legacies of such definitions flowing from the nineteenth century. Wright looks to Foucault's concept of the 'dangerous individual' to unpack these ideas and to call for new ways of reforming the criminal justice system.

The issue then moves to two articles about higher education, firstly in relation to working-class students, and secondly in regard to academics from working-class backgrounds. In 'Divergent Approaches to Access: How Selective College Admissions Offices Recruit Lower-Income, First-Generation, and Working-Class Students', Hannah Gunter and Janel Benson consider the methods used by selective colleges in the US to recruit students and examine their approaches to recruiting working-class students. They find that the colleges with greater numbers of first- 
in-family, low-income, and working-class students, are those that consciously recruit these students by targeting low-income area schools and providing access to information about campuses and programs to prospective students.

Teresa Crew's article 'Navigating Academia as a Working-Class Academic' provides insights into the experiences of British academics from working-class backgrounds who have been faced with classism in their workplaces through micro-aggressions and a tendency for institutions to see a working-class background as a deficit rather than an asset. Crew's interviews with working-class academics provide valuable understandings of the kinds of prejudices faced and the impact this has on the working-class academics' work and lives.

Changing tack is Robert Francis' study of the labor participation of working-class men in rural Pennsylvania. In 'Missing Men? Precarity and Declining Labor Force Participation Among Working-Class Men', Francis analyses qualitative data collected from interviews with working-class men to ascertain why they might have periods of non-participation in the workforce. His findings suggest that raw figures on such non-participation do not give a full picture of why some men might have periods of apparent unemployment, and do also not take into account the role of the informal economy in the men's working lives.

Following is 'Social and Economic Costs of Inequality in the State of Virginia' which is a datadriven article by Lawrence M. Eppard, Erik Nelson, Michael McLaughlin and Theresa Ward, which details some of the social and economic costs of inequality in Virginia. The authors look at a variety of measures that indicate inequality such as household income and racial segregation and show that there are large difference across counties. They conclude that the impact of such inequalities, that starts in childhood and carries through to adulthood, ends up costing in huge cost to the state in terms of economic potential,

The last article in this issue is a creative non-fiction piece by Alice Wittenburg that looks at the tension between economies and the environment that has played out in the history of the Mahoning River in Ohio. In 'A Dozen Images Made in or Near Youngstown, Ohio, That Show Why People Need Both Jobs and Fish', the focus is on Youngstown, a former industrial city that once considered the levels of industrial pollution in the river as a sign that the town was prospering. Wittenburg uses a series of images to tell the story of the river and the city and to reveal how the people have regarded the river and ultimately how a balance can be found between the need for jobs, and the health of the ecosystem.

There is also a great selection of book reviews, edited by the book reviews editor, Christie Launius. Once again the reviews show the levels of interest in working-class studies shown by scholars and authors. Books being reviewed include the new Handbook of Working-Class Studies which will be a great place for anyone new to the field to start. Other topics in the books being reviewed are poverty in America, the impact of unemployment, working-class environmentalism, working-class cinema, as well as four reviews of creative works including an autobiography, a memoir, a diary of a pandemic nurse and a collection of poetry.

The editors thank all the contributors, and the reviewers who shared their expertise. We hope that readers enjoy this issue and we thank you too for your readership. Let us all keep working towards racial justice, economic equality and for climate justice. Together we are strong. 